\title{
CORRIGENDUM
}

Genes \& Development 31: 959-972 (2017)

\section{Corrigendum: p53 is essential for DNA methylation homeostasis in naïve embryonic stem cells, and its loss promotes clonal heterogeneity}

Ayala Tovy, Adam Spiro, Ryan McCarthy, Zohar Shipony, Yael Aylon, Kendra Allton, Elena Ainbinder, Noa Furth, Amos Tanay, Michelle Barton, and Moshe Oren

The authors note that, in the Materials and Methods section of the above-mentioned article, details of the antibodies used for CyTOF analysis (Supplemental Table 4) were inadvertently omitted. Supplemental Table 4, which lists these antibodies, has now been added online, and the Materials and Methods section in the article has been updated to reflect this addition.

doi: $10.1101 / \operatorname{gad} .319863 .118$ 


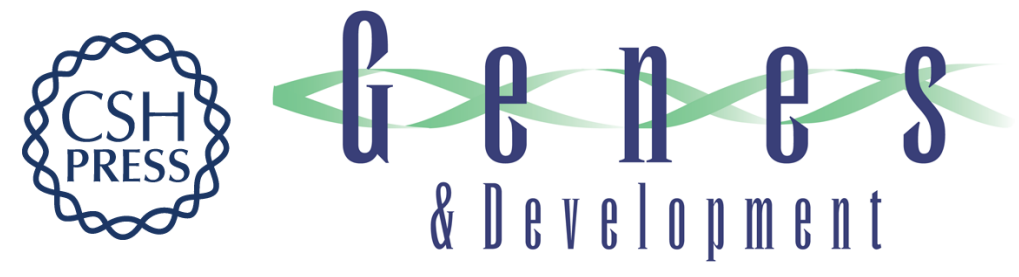

\section{Corrigendum: p53 is essential for DNA methylation homeostasis in naïve embryonic stem cells, and its loss promotes clonal heterogeneity}

Ayala Tovy, Adam Spiro, Ryan McCarthy, et al.

Genes Dev. 2018, 32:

Access the most recent version at doi:10.1101/gad.319863.118
Related Content p53 is essential for DNA methylation homeostasis in naïve embryonic stem cells, and its loss promotes clonal heterogeneity
Ayala Tovy, Adam Spiro, Ryan McCarthy, et al.
Genes Dev. May , 2017 31: 959-972

\section{License}
Email Alerting
Service
Receive free email alerts when new articles cite this article - sign up in the box at the top right corner of the article or click here.

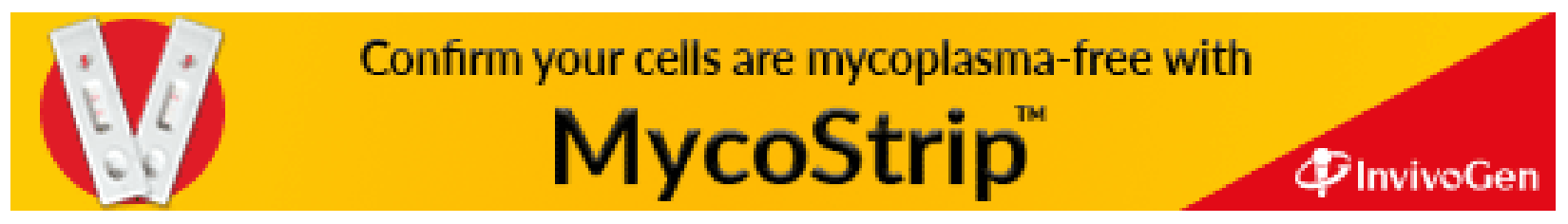

